\title{
The role of the oncostatin M/OSM receptor $\beta$ axis in activating dermal microvascular endothelial cells in systemic sclerosis
}

\author{
G. Marden ${ }^{1 \dagger}$, Q. Wan ${ }^{1,2 \dagger}$, J. Wilks ${ }^{1}$, K. Nevin ${ }^{3}$, M. Feeney ${ }^{3}$, N. Wisniacki ${ }^{3}$, M. Trojanowski ${ }^{1}$, A. Bujor ${ }^{1}$, L. Stawski ${ }^{1}$ and \\ M. Trojanowska ${ }^{1 *}$ (D)
}

\begin{abstract}
Background: Scleroderma (SSc) is a rare autoimmune disease characterized by vascular impairment and progressive fibrosis of the skin and other organs. Oncostatin M, a member of the IL-6 family, is elevated in SSC serum and was recognized as a significant player in various stages of fibrosis. The goal of this study was to assess the contribution of the OSM/OSMRß pathway to endothelial cell (EC) injury and activation in SSC.

Methods: IHC and IF were used to assess the distribution of OSM and OSMR $\beta$ in SSC $(n=14)$ and healthy control $(n=7)$ skin biopsies. Cell culture experiments were performed in human dermal microvascular endothelial cells (HDMECs) and included mRNA and protein analysis, and cell migration and proliferation assays. Ex vivo skin organoid culture was used to evaluate the effect of OSM on perivascular fibrosis.
\end{abstract}

Results: OSMRß protein was elevated in dermal ECs and in fibroblasts of SSC patients. Treatments of HDMECs with OSM or IL-6+SIL-6R have demonstrated that both cytokines similarly stimulated proinflammatory genes and genes related to endothelial to mesenchymal transition (EndMT). OSM was more effective than IL-6+SIL-6R in inducing cell migration, while both treatments similarly induced cell proliferation. The effects of OSM were mediated via OSMR $\beta$ and STAT3, while the LIFR did not contribute to these responses. Both OSM and IL-6+SIL-6R induced profibrotic gene expression in HDMECs, as well as expansion of the perivascular PDGFR $\beta^{+}$cells in the ex vivo human skin culture system. Additional studies in HDMECs showed that siRNA-mediated downregulation of FLI1 and its close homolog ERG resulted in increased expression of OSMRß in HDMECs.

Conclusions: This work provides new insights into the role of the OSM/OSMRß axis in activation/injury of dermal ECS and supports the involvement of this pathway in SSC vascular disease.

Keywords: OSM, OSMRß, IL-6, Endothelial cells, SSC, FLI1, ERG

\footnotetext{
* Correspondence: trojanme@bu.edu

${ }^{\dagger} \mathrm{G}$. Marden and Q. Wan contributed equally to this work.

${ }^{1}$ Arthritis Centre, Boston University School of Medicine, Boston University, 72 East Concord St, E-5, Boston, MA 02118, USA

Full list of author information is available at the end of the article
}

C C The Author(s). 2020 Open Access This article is licensed under a Creative Commons Attribution 4.0 International License, which permits use, sharing, adaptation, distribution and reproduction in any medium or format, as long as you give appropriate credit to the original author(s) and the source, provide a link to the Creative Commons licence, and indicate if changes were made. The images or other third party material in this article are included in the article's Creative Commons licence, unless indicated otherwise in a credit line to the material. If material is not included in the article's Creative Commons licence and your intended use is not permitted by statutory regulation or exceeds the permitted use, you will need to obtain permission directly from the copyright holder. To view a copy of this licence, visit http://creativecommons.org/licenses/by/4.0/ The Creative Commons Public Domain Dedication waiver (http://creativecommons.org/publicdomain/zero/1.0/) applies to the data made available in this article, unless otherwise stated in a credit line to the data. 


\section{Introduction}

Scleroderma also known as systemic sclerosis (SSc) is a complex chronic multisystem disease of unknown etiology that is characterized by early vascular damage with activation of the immune system, followed by skin and internal organ fibrosis [1]. The widespread structural changes of the microvasculature are well documented in SSc patients; however, many aspects of SSc vasculopathy, including the nature of the injury and the pathological consequences of injured endothelial cells (ECs), remain poorly understood. ECs play an important role in orchestrating tissue response to injury [2, 3]. In addition to the secretion of proinflammatory and profibrotic cytokines, ECs may also contribute to the perivascular extracellular matrix (ECM) remodeling by transitioning to mesenchymal cells through the process of endothelial to mesenchymal transition (EndMT), as well as through more direct interactions with fibroblasts [4]. Although, the presence of EndMT was reported in several animal models of inducible fibrosis, [5] as well as the skin and lungs of scleroderma patients [6], contribution of EndMT to the pathogenesis of fibrotic diseases remains controversial.

The IL-6 cytokine family encompasses a group of pleiotropic cytokines produced by a variety of cells in response to inflammatory stimuli [7]. This cytokine family shares a common signal transducer gp130 in the receptor complex. Members of the IL- 6 family activate the JAK/STAT and MAPK signaling pathways and are involved in many biological processes including differentiation, hematopoiesis, cell proliferation, and cell survival [7]. Increased levels of IL-6 family members, including oncostatin M (OSM) and IL-6, have been reported in many pathological conditions characterized by chronic inflammation, vascular injury, and fibrosis including SSc [8]. Moreover, targeting IL-6 has been beneficial in many diseases including those characterized by ECM remodeling $[9,10]$. OSM was shown to play an important role in various stages of the fibrotic process including inflammation and activation of fibroblasts $[11,12]$. However, its role in activating ECs is still poorly explored, despite the fact that ECs express high levels of OSMR $\beta$ making them one of the primary targets of OSM. The goal of this study was to assess the effects of OSM on EC activation and the potential contribution of OSM signaling to SSc pathogenesis.

\section{Material and methods}

\section{Human subjects}

Upon informed consent and in compliance with the Institutional Review Board (IRB) for Human Studies, skin biopsies from the affected areas were obtained from nine patients with diffuse SSc, eight patients with limited SSc, and seven healthy donors. Patient characteristics are included from the affected areas were obtained from nine patients with diffuse SSc, eight patients with limited SSc, and seven healthy donors. Patient characteristics are included in Table 1.

\section{Cells}

Human dermal microvascular endothelial cells (HDME Cs) were isolated from human foreskin as previously described [13, 14]. The human biological samples were sourced ethically, and their research use was in accord with the terms of the informed consent under an IRB/ EC-approved protocol. Cells were cultured on bovine collagen-coated 6-well plates in EBM medium supplemented with $10 \%$ FBS, and EC growth supplement mix at $37^{\circ} \mathrm{C}$ with $5 \% \mathrm{CO}_{2}$ in air. All the experiments were performed on cells from early passages.

\section{siRNA transient transfections}

HDMECs were transfected with siRNA specific to human OSMR $\beta$, LIFR, ERG, and FLI1 (ON-TARG ETplus SMART pool; GE Dharmacon, Lafayette, CO) or negative control siRNA at the concentration of 10 nM using Lipofectamine RNAiMAX Transfection Reagent (Thermo Fisher Scientific, Waltham, MA) according to the manufacturer's protocol.

\section{Western blot}

For Western blot, whole-cell extracts were prepared from HDMECs using lysis buffer with the following composition: $1 \%$ Triton X-100, $50 \mathrm{mmol} / \mathrm{L}$ Tris- $\mathrm{HCl}$ (pH 7.4), 150 $\mathrm{mmol} / \mathrm{L} \mathrm{NaCl}, 3 \mathrm{mmol} / \mathrm{L} \mathrm{MgCl}_{2}, 1 \mathrm{mmol} / \mathrm{L} \mathrm{CaCl}_{2}$, proteinase inhibitor mixture (Roche), and $1 \mathrm{mmol} / \mathrm{L}$ phenylmethyl sulfonyl fluoride. Protein extracts were subjected to SDSPAGE and transferred to nitrocellulose membranes. Membranes were incubated overnight with primary antibodies, washed, and incubated for $1 \mathrm{~h}$ with appropriate horseradish peroxidase-conjugated secondary antibody. After washing, visualization was performed by enhanced chemiluminescence (Pierce, Rockford, IL). Primary antibodies and concentrations are listed in Supplemental Table II.

\section{Quantitative RT-PCR analysis}

Total RNA was isolated using TRIzol reagent (MRC, Inc., Cincinnati, OH). Real-time PCR assays were performed using the StepOnePlus Real-Time PCR system (Applied Biosystems, Foster City, CA). Briefly, $1 \mu \mathrm{g}$ of total RNA was reverse transcribed with random hexamers using the Transcriptor First Strand complementary DNA Synthesis kit (Roche Applied Science, Indianapolis, IN) according to the manufacturer's protocol. The amplification mixture $(10 \mu \mathrm{l})$ contained $1 \mu \mathrm{l}$ of complementary DNA, $0.5 \mu \mathrm{M}$ of each primer, and $5 \mu \mathrm{l}$ of SYBR Green PCR Master Mix. The primers are listed in Supplementary Table I. Relative changes in 
Table 1 Healthy controls and Scleroderma patient's data

\begin{tabular}{|c|c|c|c|c|c|c|}
\hline Name & Sex & Age & Disease duration & Skin score & Endothelial cells/perivascular cells & Fibroblasts \\
\hline $\mathrm{HC1}$ & $\mathrm{F}$ & 42 & - & & + & - \\
\hline $\mathrm{HC2}$ & $\mathrm{F}$ & 28 & - & & ++ & + \\
\hline $\mathrm{HC} 3$ & $\mathrm{~F}$ & 52 & - & & + & - \\
\hline $\mathrm{HC} 4$ & M & 28 & - & & + & - \\
\hline Diffuse SSC 1 & $\mathrm{~F}$ & 62 & 2 years & 24 & ++ & + \\
\hline Diffuse SSc 2 & $\mathrm{~F}$ & 47 & 1 year & 15 & +++ & ++ \\
\hline Diffuse SSc 3 & $\mathrm{~F}$ & 47 & 8 years & 15 & +++ & ++ \\
\hline Diffuse SSC 4 & $\mathrm{~F}$ & 72 & 1 year & 34 & ++ & ++ \\
\hline Diffuse SSC 5 & M & 33 & 3 years & 18 & ++ & ++ \\
\hline Diffuse SSC 6 & M & 36 & 7 years & 35 & +++ & ++ \\
\hline Diffuse SSC 7 & M & 61 & 5 years & 54 & +++ & ++ \\
\hline Limited SSc 1 & $\mathrm{~F}$ & 42 & 2 years & 3 & +++ & ++ \\
\hline Limited SSc 2 & $\mathrm{~F}$ & 52 & 2 years & 3 & ++ & + \\
\hline Limited SSc 3 & $\mathrm{~F}$ & 42 & 2 years & 4 & ++ & ++ \\
\hline Limited SSc 4 & $\mathrm{~F}$ & 68 & 1 year & 0 & + & + \\
\hline Limited SSC 5 & $\mathrm{~F}$ & 37 & 1 year & 2 & ++ & + \\
\hline Limited SSc 6 & $\mathrm{~F}$ & 52 & 5 years & 16 & ++ & ++ \\
\hline Limited SSC 7 & $\mathrm{~F}$ & 44 & 2 years & 3 & +++ & + \\
\hline \multicolumn{7}{|c|}{ Biopsies used in IF } \\
\hline HC 4 & $\mathrm{~F}$ & 63 & & & & \\
\hline HC 5 & M & 44 & & & & \\
\hline HC 6 & $\mathrm{~F}$ & 50 & & & & \\
\hline Diffuse SSC 8 & $\mathrm{~F}$ & 60 & 5 years & 12 & & \\
\hline Diffuse SSC 9 & M & 62 & 2 months & 23 & & \\
\hline Limited SSc 10 & $\mathrm{~F}$ & 74 & 4 years & 0 & & \\
\hline
\end{tabular}

$F$ female, $M$ male

the levels of genes of interest were determined by the $2^{-\Delta \Delta C \mathrm{~T}}$ method.

\section{Immunofluorescence staining on adherent cell cultures}

For immunofluorescence, cultured HDMECs were grown on collagen-coated cover slips. Cells were treated with OSM and IL-6+sIL6R for $48 \mathrm{~h}$ and $72 \mathrm{~h}$, or siRNA for ERG and FLI1. Cells were fixed with $4 \%$ paraformaldehyde for $15 \mathrm{~min}$. Non-specific protein binding was blocked with 3\% BSA for $1 \mathrm{~h}$. Next, cells were incubated at $4{ }^{\circ} \mathrm{C}$ overnight with primary antibody. After washing, cell cultures were incubated with appropriate fluorophore-conjugated secondary antibody (Invitrogen, Carlsbad, CA) for $1.5 \mathrm{~h}$. Skin biopsies were embedded in OCT and fixed in acetone:methanol (1:1). Sections were blocked in 3\% BSA for $1 \mathrm{~h}$, before the addition of primary antibodies diluted in 1\% BSA. After washing, sections were incubated in appropriate fluorophoreconjugated secondary antibodies for $45 \mathrm{~min}$. Cells and biopsy sections were mounted on slides using Vectashield with DAPI (Vector Laboratories, Burlingame, CA) and examined using a FluoView FV10i confocal microscope system (Olympus, Center Valley, PA) at $488 \mathrm{~nm}$ (green), $594 \mathrm{~nm}$ (red), and $405 \mathrm{~nm}$ (blue). Secondary Alexafluor antibodies (Invitrogen, Carlsbad, CA) were used for each stain. Primary antibodies and concentrations are listed in Supplemental Table II.

\section{Migration and proliferation assay}

Migration and proliferation were examined using the Essen BioScience IncuCyteTM Live-Cell Imaging system. Briefly, HDMECs were plated on an ImageLock 96-well plate and grown to $100 \%$ confluence (for the migration) or $5-10 \%$ confluence (for the proliferation) cells were treated additionally with 10,50 , and $100 \mathrm{ng} / \mathrm{ml}$ of OSM or IL- 6 and sIL-6R images were captured every $3 \mathrm{~h}$ for a total of $50 \mathrm{~h}$. Area under curves was measured using the GraphPad Prism software.

\section{Immunohistochemistry}

Immunohistochemistry was performed on formalinfixed, paraffin-embedded skin tissue sections. Briefly, 
sections $(5-\mu \mathrm{m}$ thick) were deparaffinized with HistoClear (National Diagnostics, Atlanta, GA), and rehydrated through a graded series of ethanol. For OSMR $\beta$, endogenous peroxidase was blocked by incubation in 3\% hydrogen peroxide for $30 \mathrm{~min}$, followed by normal blocking serum for $1 \mathrm{~h}$. The sections were then incubated overnight at $4{ }^{\circ} \mathrm{C}$ with primary antibody diluted in blocking buffer, followed by incubation for $30 \mathrm{~min}$ with appropriate polymer detection kit. Immunoreactivity was visualized with NovaRED (Vector Laboratories, Burlingame, CA). For OSM, antigen retrieval was performed using $1 \mathrm{mM}$ Tris-EDTA pH 9.0. Sections were blocked with TBS containing 5\% normal horse serum and then incubated overnight at $4{ }^{\circ} \mathrm{C}$ with primary antibody. Appropriate polymer detection kit was used for a subsequent 30-min incubation. Immunoreactivity was visualized with diaminobenzidine (Vector Laboratories, Burlingame, CA), and sections were counterstained with hematoxylin. For double staining, slides were prepared as described and incubated with primary antibody overnight. Subsequent appropriate polymer detection kit was used, and immunoreactivity was visualized with NovaRED (Vector Laboratories, Burlingame, CA). Quenching was achieved with 3\% hydrogen peroxide. Sections were incubated in a primary antibody. Appropriate polymer detection kit was used, and immunoreactivity was visualized with high depth blue (Enzo Life Sciences, Farmingdale, NY). Images were collected using a microscope (BH-2; Olympus, Center Valley, PA). ImmPRESS HRP Polymer Detection Kits (Vector Laboratories, Burlingame, CA) were used for each stain. Primary antibodies and concentrations are listed in Supplemental Table II.

\section{Histologic assessment}

The OSMR $\beta$ staining intensity for immunohistochemistry was scored semiquantitatively. The staining intensity (1, negative or weak staining; 2 , moderate staining; and 3 , strong staining) was evaluated in six randomly selected fields in subcutaneous area. Then a semiquantitative score per sample was generated by calculating the average of the six intensity scores per sample. Semiquantitative analysis was performed by two independent blinded researchers.

\section{Gomori's trichrome staining}

Gomori's trichrome staining was used to detect collagen deposition. The skin samples were fixed in $4 \%$ paraformaldehyde for $24 \mathrm{~h}$ and then processed for paraffin embedding. Staining was performed on $5-\mu \mathrm{m}$-thick paraffin sections following the manufacturer's instructions (Chromaview, Dublin, OH, Gomori's Trichrome Blue Collagen Kit cat\# S7440-19). Collagen fibers were stained blue, nuclei were stained black, and the background was stained red.

\section{Human skin organoid culture ex vivo}

We utilized the previously described dermal ex vivo organoid culture technique [15]. The human biological samples were sourced ethically, and their research use was in accord with the terms of informed consent under an IRB/EC-approved protocol. Briefly, dermal biopsy punches $(6 \mathrm{~mm})$ obtained from foreskins were placed onto nitrocellulose membranes, to avoid contact with plastic or matrigel, and treated with human recombinant OSM (obtained from GlaxoSmithKline, Stevenage, UK) and IL-6+sIL-6R for 14 days. The medium was changed, and the OSM and IL-6+sIL-6R treatments were repeated every $48 \mathrm{~h}$. At day 14, tissue biopsies were collected for IHC analysis.

\section{Statistical analyses}

Data were analyzed by Student's $t$ test or Mann-Whitney $U$ test where appropriate. The level for statistical significance was set at $p \leq 0.05$.

\section{Results \\ OSMR $\beta$ is elevated in the endothelial cells and fibroblasts of limited and diffuse SSc skin biopsies}

OSMR $\beta$ was recently identified as a prognostic biomarker that correlates with progression of the skin disease in patients with diffuse systemic sclerosis (dcSSc) [16]. To illustrate the distribution of OSMR $\beta$ and OSM in SSc skin, we performed immunohistochemical (IHC) staining on biopsies from diffuse and limited patients. As shown in Fig. 1a, we observed increased expression of OSMR $\beta$ in the skin vessels of SSc patients as compared to healthy control skin. Semiquantitative scoring of the staining intensity demonstrated increased OSMR $\beta$ levels mostly in endothelial/perivascular cells and fibroblasts of SSc patients (Fig. 1b). In contrast, OSM protein, which was also detected in endothelial cells and fibroblasts, was comparable in SSc and $\mathrm{HC}$ skin biopsies (Supplemental Figure 1). Double immunofluorescence of OSMR $\beta$ and CD31 confirmed the presence of OSMR $\beta$ on ECs (Fig. 1c). OSMR $\beta$ did not appear to co-localize with $\alpha$ SMA in the skin (Fig. 1d). These results suggest that increased expression of OSMR $\beta$ on ECs could contribute to the process of vasculopathy in the skin of SSc patients.

\section{OSM regulates mRNA levels of proinflammatory genes in HDMECS}

OSM was previously shown to regulate expression of proinflammatory cytokines and adhesion molecules in ECs $[17,18]$. To assess the effect of OSM on the inflammatory phenotype of HDMECs, we examined the gene 


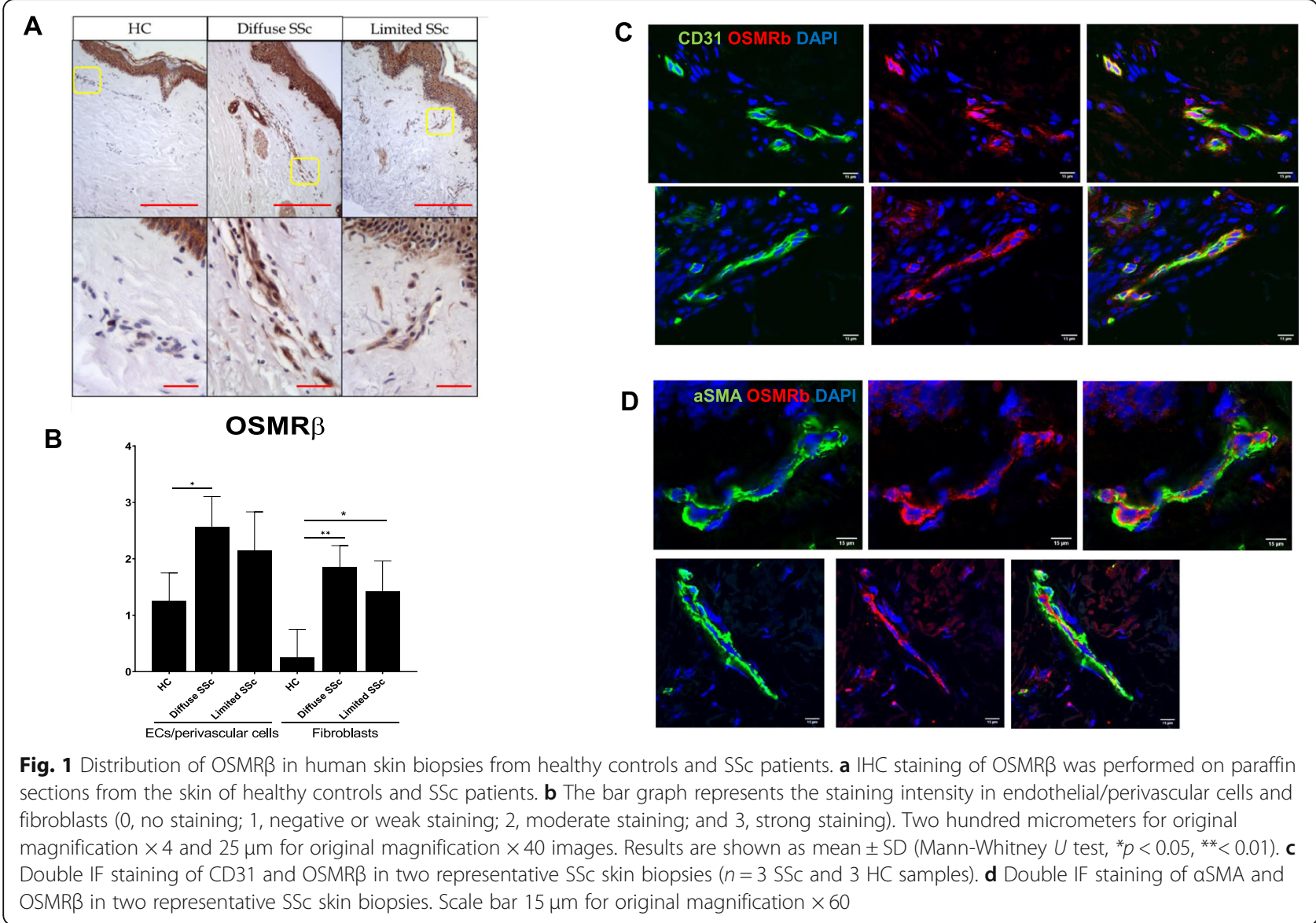

expression of selected interleukin, chemokine, and adhesion molecule genes by real-time PCR. Cells were treated with human recombinant OSM $(10 \mathrm{ng} / \mathrm{ml})$ for 3 and 24 h. Human recombinant IL-6 $(100 \mathrm{ng} / \mathrm{ml})$ was used for comparisons. Since HDMECs have very low expression of IL-6R, addition of soluble IL-6R (sIL-6R) was required to initiate IL-6 signaling. A rapid increase in IL-6 mRNA levels in cells treated with OSM and IL-6+sIL-6R occurred at $3 \mathrm{~h}$ and remained high at $24 \mathrm{~h}$ (Fig. 2a). Expression levels of other IL-6 family members, including LIF and OSM were unchanged (data not shown). We also observed increased mRNA levels of IL33 and its receptor IL1R1 in cells treated with OSM and IL-6+sIL-6R for $3 \mathrm{~h}$ and $24 \mathrm{~h}$ (Fig. 2a). Among the chemokines, increased mRNA levels of CCL7 (also known as MCP3), CXCL12, and CXCL2 were observed in response to both treatments at $3 \mathrm{~h}$ and $24 \mathrm{~h}$ (Fig. $2 \mathrm{~b}$ ). The expression of adhesion molecule ICAM-1 was increased only at the 3 $\mathrm{h}$ timepoint in cells treated with OSM and IL-6+sIL-6R (Fig. 2c). OSM seemed to be a more potent inducer of CCL7 than IL-6+sIL-6R (Fig. 2b). Furthermore, induction of IL33 was sustained at the $24 \mathrm{~h}$ timepoint by OSM, while high variability with IL-6+sIL-6R-treated HDMECs resulted in an increase that was not statistically significant (Fig. 2a). Expression of other adhesion molecules, including ICAM-2 and VCAM-1 were unchanged (data not shown). Interestingly, JUP (also known as plakoglobin or gamma catenin) and CAV1 mRNA levels were gradually decreasing over time with both treatments (Fig. 2c). These data suggest that both OSM and IL-6+sIL-6R can induce a proinflammatory phenotype in HDMECs; however, IL- 6 required a $10 \times$ higher concentration and the addition of the sIL-6R to achieve comparable results.

\section{OSM stimulates transition to a mesenchymal phenotype in HDMECs}

Previous studies have shown that bovine aortic endothelial cells (BAEC) treated with OSM became spindleshaped and exhibited increased proliferation and migration [19]. Likewise, we found that HDMECs treated with human recombinant OSM $(10 \mathrm{ng} / \mathrm{ml})$ showed a statistically significant increase in mRNA levels of selected EndMT genes, including SNAIL1, TGF 33 , ET-1, and TGF $\beta 3 \mathrm{R}$ at $3 \mathrm{~h}$ and $24 \mathrm{~h}$ when compared to the controls (Fig. 3a). Treatment with human recombinant IL-6+sIL$6 \mathrm{R}$ had similar effects on the mRNA levels of TGF $\beta 3$, ET-1, and TGF $\beta 3 R$; however, significant changes to 


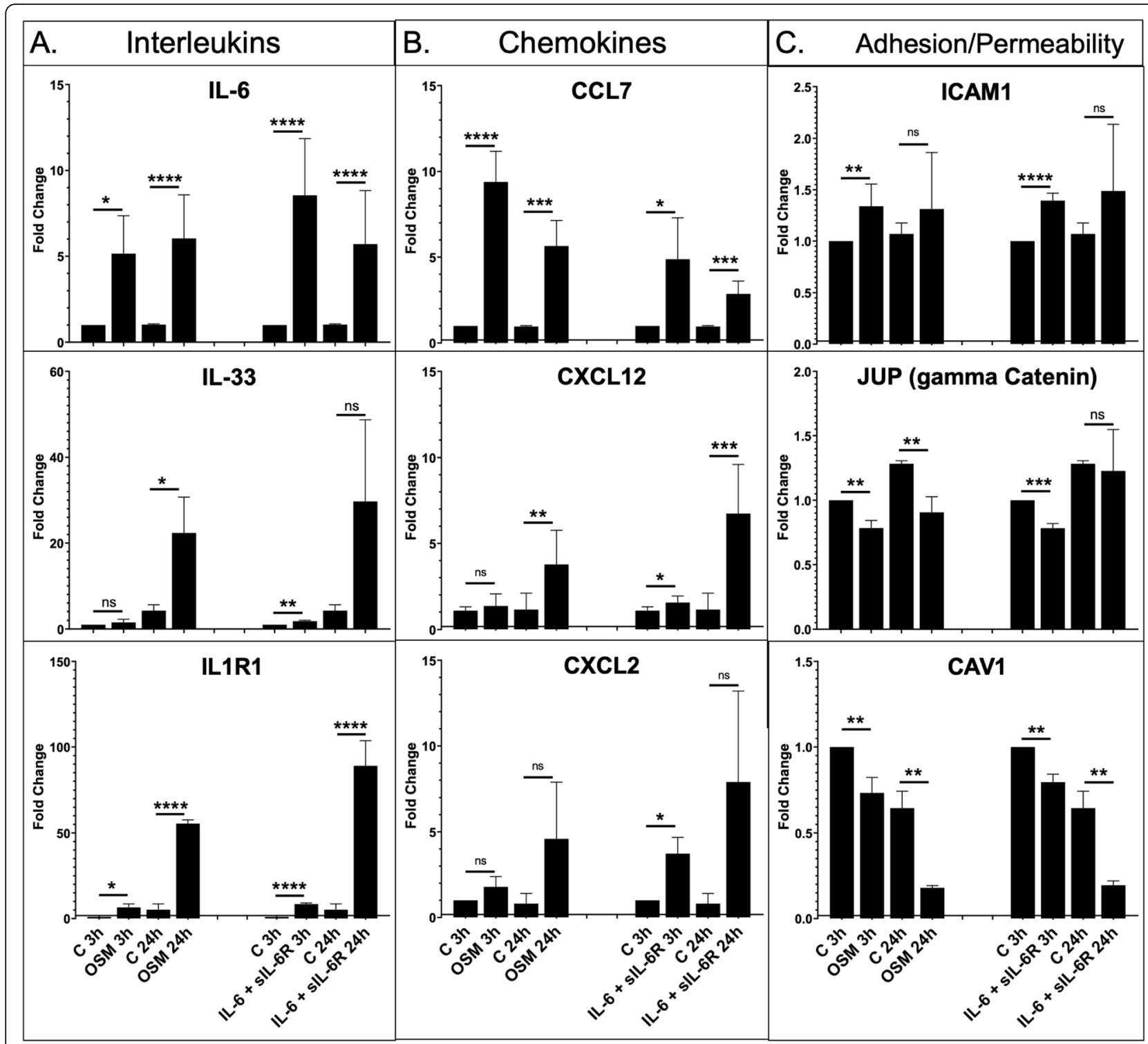

Fig. 2 Effect of OSM and IL-6+sIL-6R on the mRNA levels of inflammatory genes in HDMECs. mRNA levels of interleukins (a), chemokines (b), and adhesion/permeability genes $(\mathbf{c})$ were analyzed by quantitative PCR, $n=3$. Student's $t$ test ${ }^{*} p<0.05,{ }^{* *} p<0.01,{ }^{* * *} p<0.001{ }^{* *^{* *}} p<0.0001$

mRNA levels of SNAIL1 were only observed at $24 \mathrm{~h}$ (Fig. 3a).

To determine the effect of OSM and IL-6+sIL-6R on EC morphology, we performed double-fluorescence staining for VE-cadherin and phalloidin. HDMECs treated with OSM showed decreased VE-cadherin staining as well as elongated F-actin stress fibers at $48 \mathrm{~h}$ and $72 \mathrm{~h}$ (Fig. 3b). In contrast, treatment with IL-6+sIL-6R showed similar changes only at $72 \mathrm{~h}$ (Fig. 3b). Western blot analysis confirmed decreased levels of endothelial markers such as VE-cadherin and CD31 and increased levels of $\alpha$ SMA and TGF $\beta 1,-2,-3$ at $24 \mathrm{~h}$ and $48 \mathrm{~h}$ timepoints in cells treated with OSM or IL-6+sIL-6R (Fig. 3c). Together, these data suggest that both OSM and IL-6+
sIL-6R can induce morphological EndMT-like changes in HDMECs with OSM acting more rapidly when compared to IL-6+sIL6R.

Because cells undergoing EndMT could acquire a more migratory phenotype, we assessed the effect of OSM and IL-6+sIL-6R on HDMEC migration using the scratch assay provided by the Essen BioScience IncuCyteTM Live-Cell Imaging system. HDMECs were treated with OSM and IL6+sIL-6R at the concentrations of 10,50 , and $100 \mathrm{ng} / \mathrm{ml}$ for $50 \mathrm{~h}$. Cells stimulated with OSM showed significantly increased migration at the lowest dose, while the higher doses had no additional effect. In contrast, in cells treated with IL-6+sIL-6R, we only observed a trend toward 


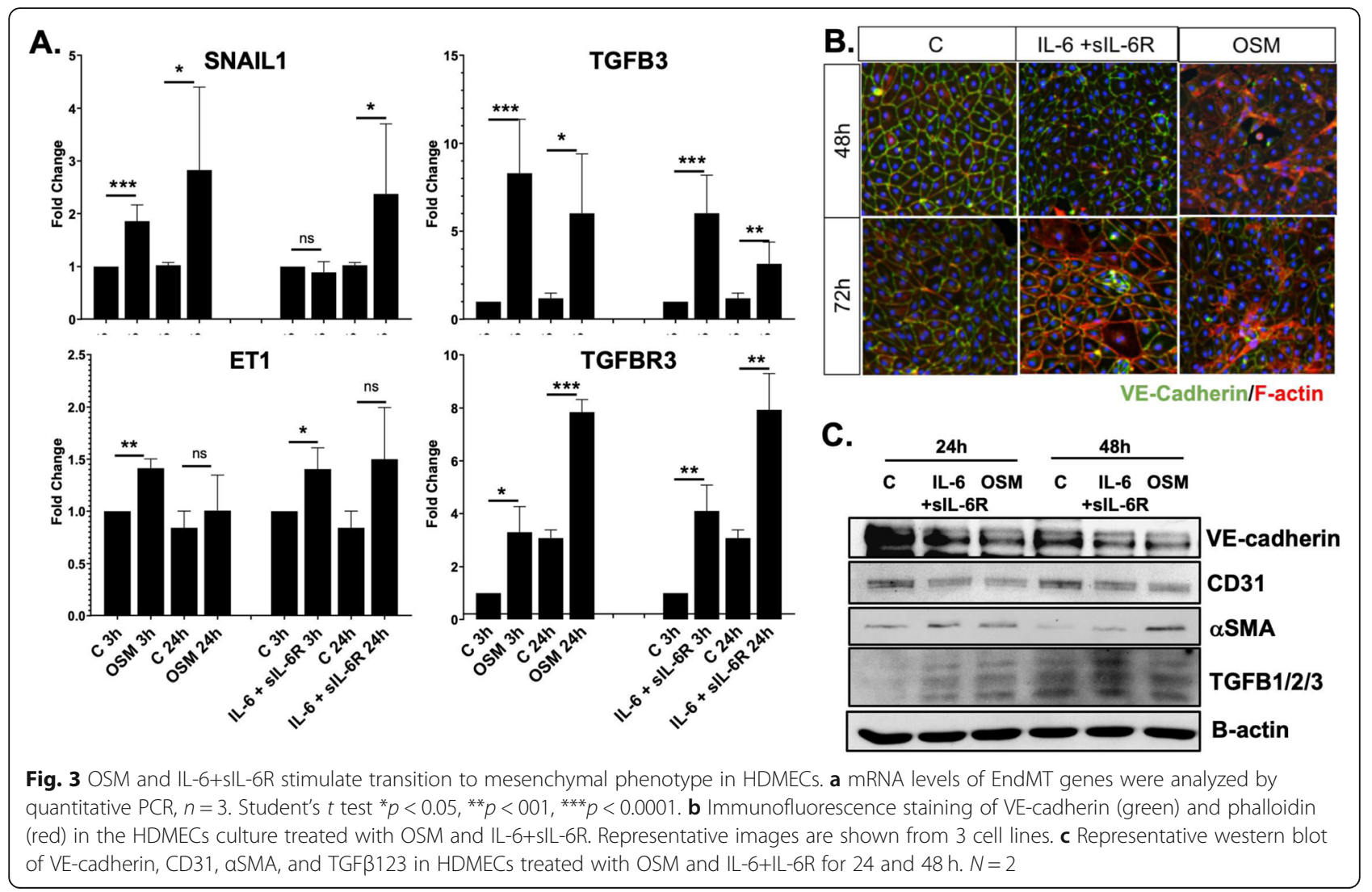

increased migration, which was not statistically significant (Supplementary Figure 2). It may be relevant to the pro-migratory effects of OSM that plasminogen activation system-related genes, urokinase plasminogen activator (PLAUR), and tissue plasminogen activator (PLAT), were induced by OSM only [20] (Suplementary Figure 2).

We next evaluated the effect of OSM and IL-6+sIL6R on HDMECs proliferation. Cells were treated with OSM and IL-6+sIL-6R at the concentrations of 10 , 50 , and $100 \mathrm{ng} / \mathrm{ml}$ for $50 \mathrm{~h}$. Both OSM and IL-6+sIL$6 \mathrm{R}$ significantly induced proliferation of HDMECs; however, IL-6+IL-6R increased cell proliferation at lower concentrations than OSM (Supplementary Figure 2B). OSM and IL-6+sIL-6R exhibited similar behavior in a capillary tube formation assay in the presence of $2.5 \%$ FCS; however, neither cytokine was able to efficiently induce tube formation in 1\% FCS (Supplementary Figure 2C). These data suggest that OSM compared to IL-6+sIL-6R is a more potent inducer of HDMECs migration. In contrast, IL-6+sIL$6 \mathrm{R}$, although a weak stimulator of cell migration, potently induced proliferation of HDMECs. Together these data demonstrated an important role of OSM in modulating the function of HDMECs.
OSM induces a profibrotic response in human skin organoid cultures

To further investigate the effects of OSM and IL-6+sIL$6 \mathrm{Ra}$ on vascular injury, we employed an ex vivo human skin culture system, which more closely mimics the in vivo environment. OSM or IL-6+sIL-6R-treated tissue explants showed increased collagen deposition as well as an increased number of PDGFR $\beta^{+}$cells around the vessels (Fig. 4a). To characterize those vessels, we performed double immunostaining for PDGFR $\beta$ and CD31. As shown on Fig. 4 b, in tissues treated with OSM or IL$6+$ sIL-6R, vessels with an increased number of PDGFR $\beta$ positive cells also showed decreased expression of CD31. Moreover, we observed increased expression of phosphorylated STAT3 in the vessels and in numerous stromal cells in OSM and IL-6+sIL-6R-treated skin as compared to controls (Supplementary Figure 3A). Interestingly, activation of PDGFR $\beta$ was only observed around the blood vessels, but not lymphatic vessels as illustrated by the double staining for PDGFR $\beta$ /podoplanin (PDPN) (Supplemental Figure 3B). These observations are consistent with the expansion of the perivascular mesenchymal stromal cells during fibrosis [21].

To gain additional insights into the profibrotic effects of OSM, we assessed the expression of additional profibrotic 

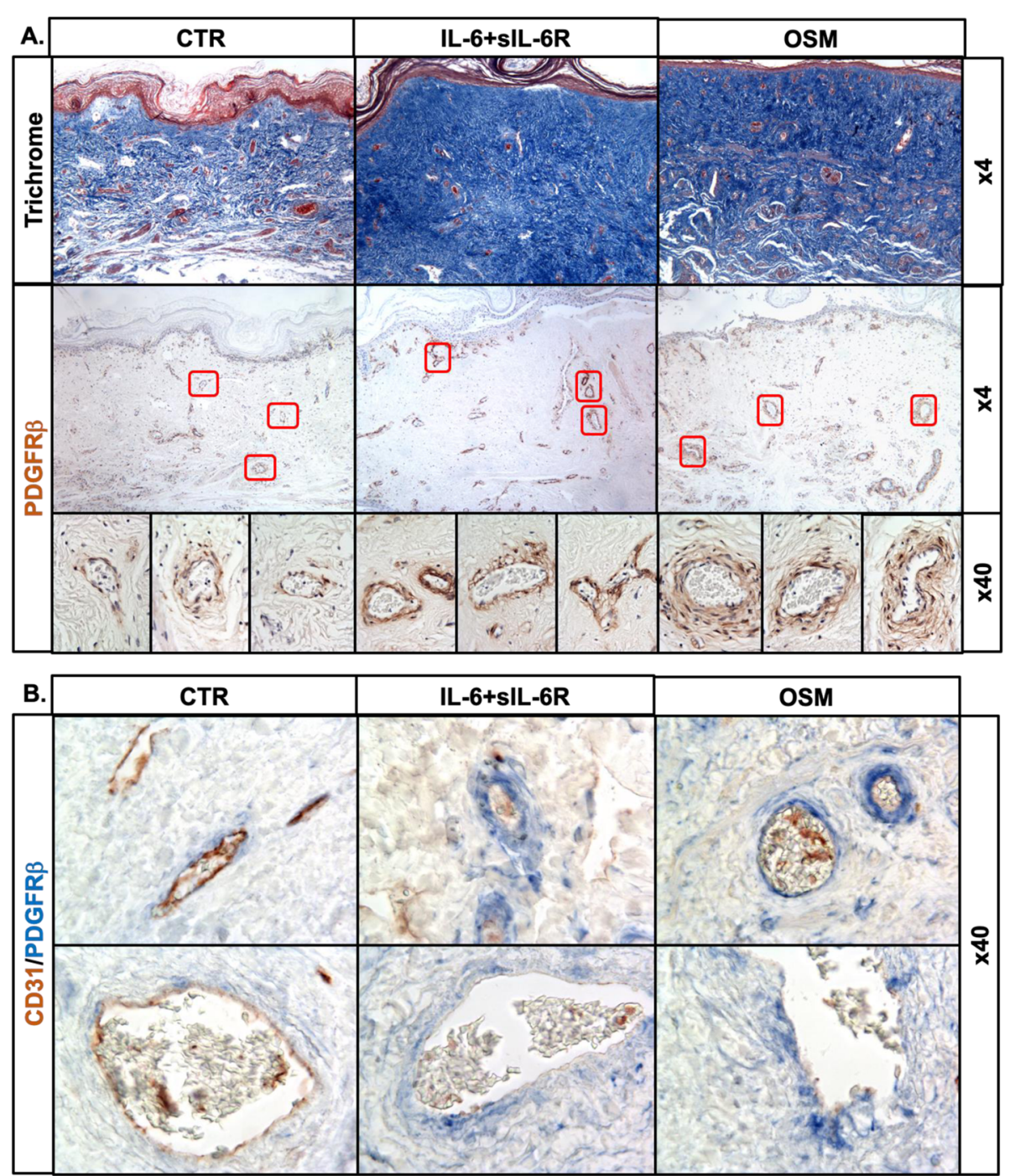

Fig. 4 Effect of OSM and IL-6+sIL-6R on human skin organoid cultures. Dermal biopsy punches $(6 \mathrm{~mm})$ obtained from foreskins were placed onto nitrocellulose membranes and treated with OSM or IL-6+IL-6R for 14 days. Stainings were performed on paraffin sections. a Trichrome staining and IHC staining of PDGFRß. b Double IHC of PDGFRß/CD31. Two hundred micrometers for original magnification $\times 4$ and $25 \mu \mathrm{m}$ for original magnification $\times 40$ images, $n=3$. c Effect of OSM and IL-6+sIL-6R on the mRNA levels of profibrotic genes in HDMECs. mRNA levels of profibrotic genes were analyzed by quantitative PCR, $n=3 .{ }^{*} p<0.05,{ }^{* *} p<0.01,{ }^{* * *} p<0.001$

genes. Cells treated with OSM or IL-6+sIL-6R, showed decreased expression of FGFR1 and increased expression of FAP, POSTN, and TIMP1 (Supplementary Figure 2). Also, CHI3L1 (YKL-40), a protein associated with fibrosis that has been implicated in SSc lung and skin fibrosis, was highly elevated by OSM, and to a lesser degree by IL-6+sIL-6R [22-25] (Supplementary Figure 2). Notably, increased expression of hyaluronan synthase (HAS2) and decreased expression of Wnt pathway inhibitor Dkk1 were only observed in cells stimulated with OSM (Supplementary Figure 2). HAS2 has been shown to regulate EndMT during cardiac valve formation [26]. Furthermore, elevated expression of HAS2 by lung fibroblasts promoted severe lung fibrosis [27]. Activation of the Wnt pathway has also been implicated in the process of EndMT [28], and downregulation of Dkk1 has been shown in SSc skin in vivo and in cultured SSc fibroblasts [29, 30].

\section{OSM-induced EC activation is mediated primarily by OSMR $\beta$ and depends on STAT3 phosphorylation}

In humans, OSM signaling is initiated by binding of OSM to its specific type I receptor complex (LIFR $\beta$ / gp130) or type II receptor complex (OSMR $\beta / g p 130)$. To determine which receptor is responsible for the OSM-induced phenotype in HDMECs, cells were treated with SCR, OSMR $\beta$ siRNA, LIFR siRNA, or 
both for $48 \mathrm{~h}$ and then stimulated with OSM for another $3 \mathrm{~h}$. Cells treated with siOSMR $\beta$, siLIFR, and both showed around $80 \%$ efficiency in downregulating these genes (Fig. 5a). Treatment with OSMR $\beta$ siRNA significantly decreased expression of IL-6, SNAIL1, and TIMP1, but only partially blocked the expression of OSM-induced TGF 33 (Fig. 5b). In contrast, treatment with LIFR siRNA had no significant effect on the OSMinduced mRNA levels of any of these genes (Fig. 5b). Treatment with both OSMR $\beta /$ LIFR siRNA completely blocked the OSM-induced mRNA levels of all tested genes (Fig. 5b). This data suggests that OSM induces activation of HDMECs primarily via OSMR $\beta$.

STAT3 is a transcription factor that is activated by IL6 family cytokines, including OSM. The levels of the activated (phosphorylated) form of STAT3 are elevated in the skin and lung of SSc patients, suggesting that it is involved in SSc pathogenesis [31, 32]. HDMECs treated with OSM or IL-6+sIL-6R showed increased phosphorylation of STAT3 (Fig. 5c). A specific inhibitor of STAT3,

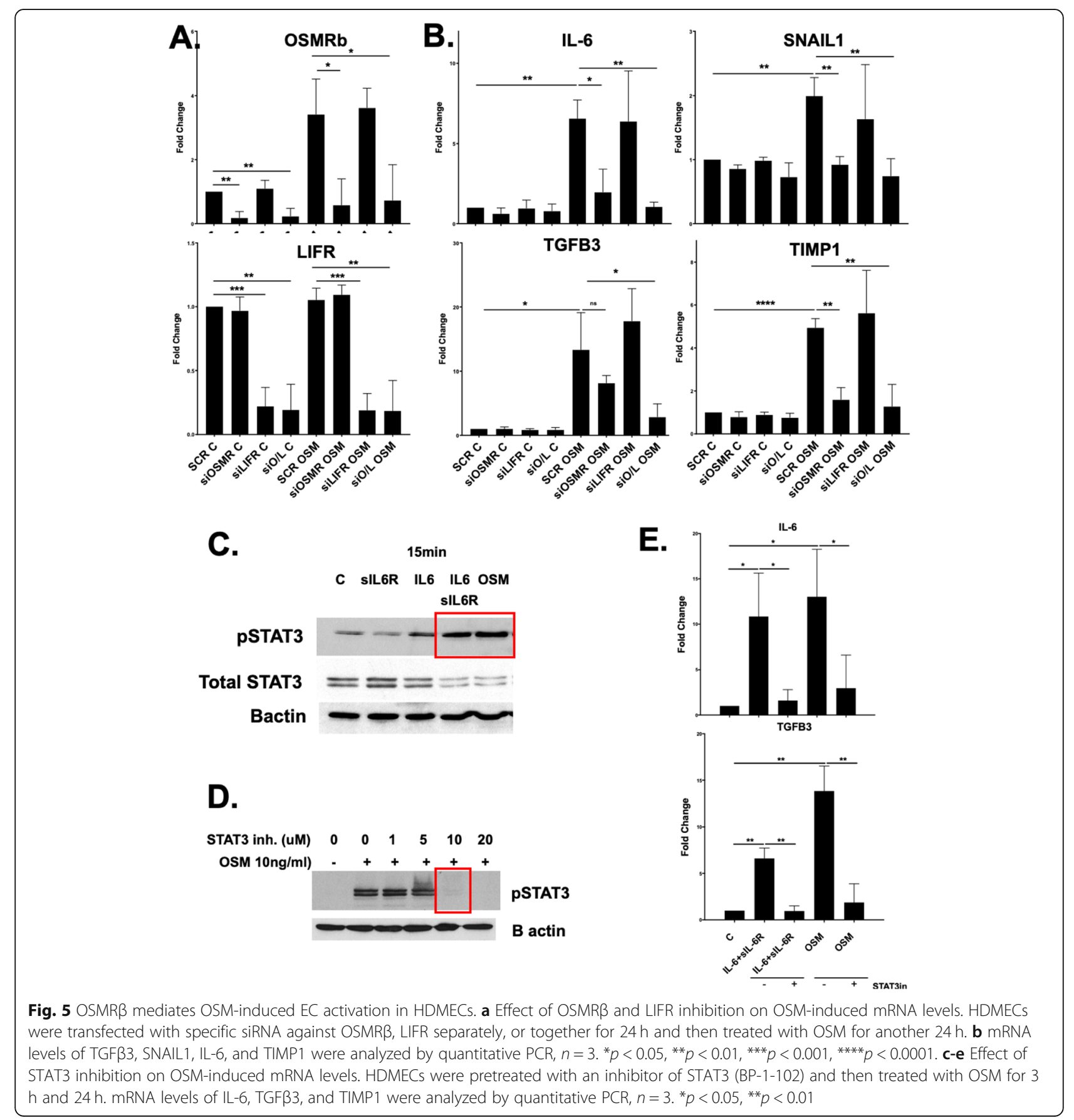


BP-1-102 (10uM), completely blocked the STAT3 phosphorylation (Fig. 5d). To determine if OSM and IL-6+ sIL-6R-induced phenotype is STAT3 dependent, we pretreated HDMECs with BP-1-102 for $1 \mathrm{~h}$, and then treated with OSM and IL-6+sIL-6R for another $3 \mathrm{~h}$ and 24h. BP-1-102 pretreatment reversed the OSM- and IL$6+$ sIL-6R-induced mRNA levels of IL- 6 and TGF $\beta 3$ (Fig. 5e). In contrast, inhibitors of TGF $\beta$ (SB431542), ERK (SCH772984), and WNT (ICG-001) signaling pathways had no effect on the OSM- and IL-6+sIL-6R-induced gene expression (data not shown). These results suggest that OSM and IL-6+sIL-6R can activate ECs directly via STAT3 phosphorylation, independent of TGF $\beta$, WNT, and ERK signaling.

\section{OSMR $\beta$ expression in HDMECs is regulated by FLI1 and ERG}

In the course of this study, we noticed that many of the effects of OSM/IL-6 on HDMECs, including downregulation of VE-cadherin and CD31, and upregulation of the profibrotic and proinflammatory genes were similar to those previously attributed to the deficiency of FLI1 [3335], thus raising the possibility that FLI1 may mediate some of the functional effects of OSM/IL-6. However, OSM/IL-6 did not affect FLI1 protein levels, suggesting that those cytokines act independently of FLI1. Since FLI1 and its close homolog, ERG, are known to suppress inflammatory responses in ECs and the expression of both factors have been shown to be reduced in SSc ECs [33, 34], we next asked whether FLI1 or ERG could be involved in regulating the expression of OSMR $\beta$. Depletion of either FLI1 or ERG led to increased mRNA and protein levels of OSMR $\beta$, suggesting that the lower protein levels of these transcription factors in SSc vasculature may, at least in part, contribute to the increased expression of OSMR $\beta$ in SSc dermal ECs (Fig. 6).

\section{Discussion}

There is increasing evidence linking IL-6 to endothelial dysfunction and vascular hypertrophy, as well as fibrosis, including SSc [36, 37]; however, the contribution of other IL- 6 family members to these pathological processes, especially the activation of ECs, remains relatively understudied. Because OSM has also been implicated in SSc pathogenesis [38, 39], this study investigated how OSM influences HDMECs. We showed that the effects of OSM were comparable to that of IL-6/IL-6R $\alpha$, with both cytokines inducing a proinflammatory and profibrotic phenotype in HDMECs and in an ex vivo skin culture system. We further demonstrated that blocking the OSMR $\beta$ or STAT3 phosphorylation reversed the OSM-induced phenotype.

STAT3, a transcriptional effector of the JAK/STAT signaling pathway, regulates many cellular processes including proliferation, migration, apoptosis, and differentiation [40]. STAT3 can be activated by proinflammatory cytokines including members of IL-6 family, IL-6, and OSM $[41,42]$. Persistent activation of STAT3 was observed in many diseases characterized by chronic inflammation and fibrosis including SSc [26]. In endothelial
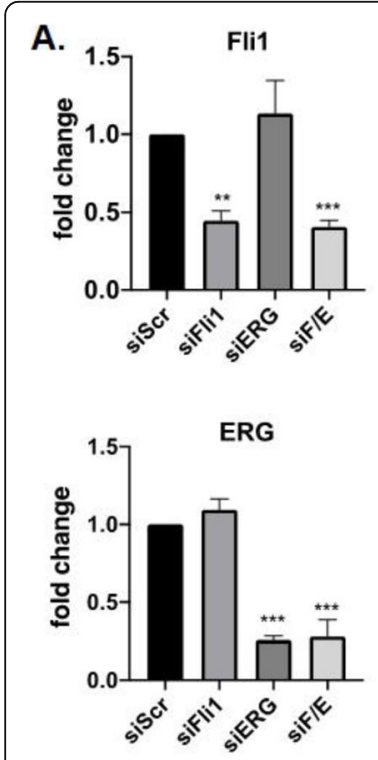

B.

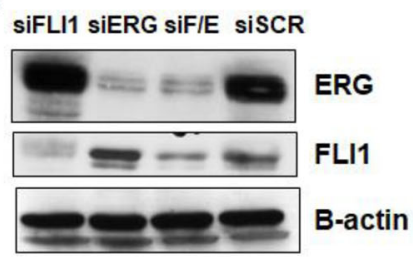

C.

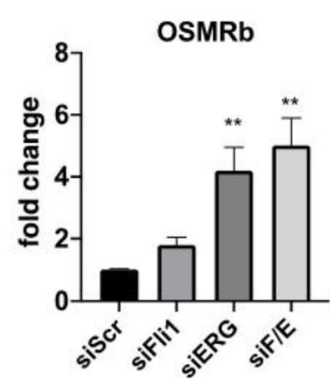

D.
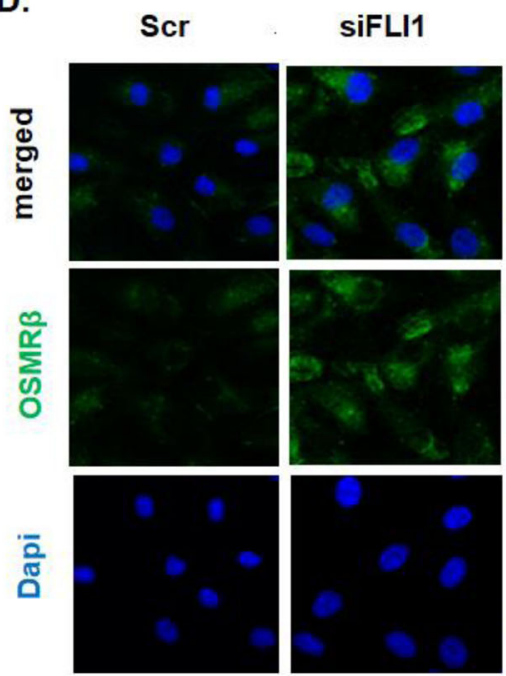

SiERG

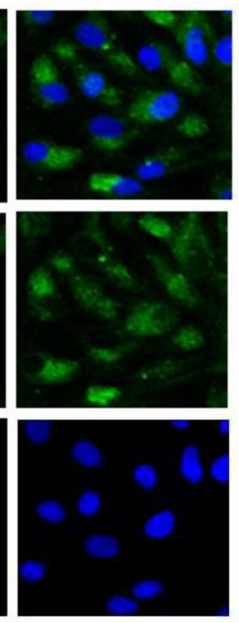

Fig. 6 FLI1 and ERG regulate OSMR $\beta$ expression in HDMECs. mRNA levels of FLI1, ERG (a), and OSMR $(\mathbf{c})$ were analyzed by quantitative PCR, $n=$ 3. ${ }^{*} p<0.05,{ }^{* *} p<0.01,{ }^{* *} p<0.001$. b Representative western blot of FLI1 and ERG in HDMECs treated with siFLI1, siERG, and siSCR oligos for 48 h. $N=3$. d Immunofluorescence staining of OSMR $\beta$ (green) in the HDMECs culture treated with OSM and IL-6+IL-6R. Representative images are shown from 3 cell lines 
cells STAT3 activation was mostly linked to increased expression of adhesion molecules including E-selectin, P-selectin, and VCAM [43, 44]. In our experiments, OSM-induced ICAM1 and junction plakoglobin JUP; however, it did not affect expression of E- and P-selectin or VCAM.

Activation of OSM signaling is strongly related to the expression levels of its receptors. It was previously shown that in fibroblasts and epithelial cells OSM can regulate the synthesis and turnover of OSMR $\beta$ and LIFR $\beta$ by ligand-induced receptor degradation as well as by a compensatory mechanism of enhanced regulation of their mRNA levels [45]. In HDMECs, OSM can induce mRNA levels of OSMR $\beta$, but not LIFR $\beta$ (data not shown), suggesting the initiation of the compensatory mechanism. Moreover, our data indicate that the OSMinduced phenotype is primarily mediated by OSMR $\beta$ in HDMECs.

Endothelial cells play a crucial role in inflammatory processes by maintaining the vessel integrity and immune cell trafficking. Excessive endothelial cell activation in chronic inflammatory settings can lead to EC dysfunction and development of a broad spectrum of human diseases [46, 47]. Here, we show that SSc dermal ECs expressed high levels of OSMR $\beta$ together with its cognate ligand, OSM, suggesting that the autocrine OSM/OSMR $\beta$ signaling could contribute to vascular inflammation in SSc. We further showed that depletion of transcription factors ERG and FLI1 in HDMECs led to the increased expression of OSMR $\beta$, consistent with the role of these factors in suppressing vascular inflammation. Although, OSM did not affect FLI1 or ERG expression in HDMECs, previous studies have shown that various inflammatory mediators, including IFN- $\alpha$, TLR ligands, and CXCL4, as well as profibrotic ligands TGF $\beta$ and ET-1, decreased protein levels of FLI1 in ECs [33, 48-50]. Similarly, ERG expression was downregulated in ECs in response to proinflammatory factors, including TNF- $\alpha$, IL-1 $\beta$, and LPS [51].

Both IL-6 and OSM were previously implicated in tissue fibrosis either by activating other profibrotic cytokines, or directly, by regulating fibroblast activation and ECM turnover. IL-6KO mice were protected from bleomycin-induced lung fibrosis [52]. Moreover, blockade of IL-6R resulted in decreased fibroblasts activation and alleviated bleomycin-induced skin fibrosis [53]. Similar observations were made for OSM. In vivo, OSM displayed profibrotic properties in different organs including the lung [12, 54], heart [55], and liver [56]. Blocking OSM was shown to ameliorate fibrosis in these organs. Similarly, blocking STAT3 with a specific inhibitor ameliorated fibrotic responses in the animal models of lung and skin fibrosis [31]. Notably, profibrotic effects of OSM in vivo are independent of TGF $\beta$ and IL-4/IL-
13 signaling pathways $[12,57]$. However, a recent study using $\mathrm{BALB} / \mathrm{c}$ mice has implicated IL-13-dependent accumulation of fibrocytes during OSM-induced lung fibrosis [54]. Consistent with these findings, we observed increased collagen deposition in ex vivo skin cultures. Notably, administration of OSM resulted in expansion of perivascular PDGFR $\beta^{+}$cells. Increased presence of PDGFR $\beta^{+}$cells was previously observed in the perivascular regions in the skin of early SSc patients and was suggested as a source of myofibroblasts [58]. In our ex vivo model, expansion of the PDGFR $\beta^{+}$cells could be caused either by OSM directly stimulating proliferation of these cells or by injured endothelial cells activating these perivascular mesenchymal cells in a paracrine manner. It would be necessary to perform more experiments to answer this question.

A phase 2 clinical trial of IL-6R $\alpha$ blocking antibody (Tociluzimab, TCZ) in SSc patients was recently completed and has shown only a trend of benefit for primary end point, mRSS [59]. However, dermal fibroblasts explanted from the TCZ-treated patients have shown complete reversal of their activated phenotype [60], the basis of these contradictory results is currently not clear but may suggest that IL-6R $\alpha$ blockade affects only a subset of fibroblasts present in the skin in vivo. The explanted fibroblasts may not fully capture the heterogeneous population of collagen-producing cells in the fibrotic lesions. It remains an open question whether blockade of OSM would be more efficacious. A clinical trial targeting OSM in patients with SSc is currently ongoing (https://clinicaltrials.gov/ct2/show/NCT03041025).

\section{Conclusions}

In summary, OSM signaling may play an important role during vessel degeneration and fibrosis in scleroderma. Blocking the OSM/OSMR $\beta$ pathway or inhibiting the STAT3 pathway could serve as a potential therapy for patients with scleroderma.

\section{Supplementary information}

Supplementary information accompanies this paper at https://doi.org/10. 1186/s13075-020-02266-0.

Additional file 1: Supplementary Figure 1. Distribution of OSM in human skin biopsies from healthy controls and SSC patients. A. $I H C$ staining of OSM was performed on paraffin sections from the skin of three SSC patients and three healthy controls $50 \mu \mathrm{m}$ scale bar for original magnification $\times 20$.

Additional file 2: Supplementary Figure 2. Effect of OSM on the mRNA levels of profibrotic genes in HDMECs. mRNA levels of profibrotic genes were analyzed by quantitative $q P C R, n=3$. Students t-test ${ }^{*} p<$ $0.05,{ }^{* *} p<0.01{ }^{* * *} p<0.001$.

Additional file 3: Supplementary Figure 3. Effect of OSM and IL$6+$ sIL-6R on migration and proliferation of HDMECs. Migration $(\mathbf{A})$ and proliferation (B) were examined with the Essen BioScience IncuCyte LiveCell Imaging system. Data represent $n=3$ wells for each point with three 
different cell cultures. $p<0.05,{ }^{*} p<0.001$. C. Matrigel tube formation assay of HDMECs stimulated with OSM or IL-6 + sIL-6R.

Additional file 4: Supplementary Figure 4. Double $\mathrm{HC}$ staining of PDGFRB/PSTAT3 and PDGFRB/PDPN in OSM treated skin cultures. Double IHC staining of PDGFRß/PSTAT3 (A) and PDGFRß/PDPN (B) was performed on paraffin sections from the OSM and IL-6+IL-6Ra treated skin cultures. $25 \mu \mathrm{m}$ for original magnification $\times 40$ images.

Additional file 5: Supplemental Table I. Human primers used for realtime PCR.

Additional file 6: Supplemental Table II. Antibodies.

\section{Competing interests}

The authors state no competing interest.

\section{Author details}

${ }^{1}$ Arthritis Centre, Boston University School of Medicine, Boston University, 72 East Concord St, E-5, Boston, MA 02118, USA. ${ }^{2}$ Department of Rheumatology and Endocrinology, Zhongnan Hospital of Wuhan University, Wuhan, China. ${ }^{3}$ Immuno-Inflammation Therapeutic Area Unit, GlaxoSmithKline, Stevenage, UK.

Received: 8 April 2020 Accepted: 9 July 2020

Published online: 31 July 2020

\section{References}

1. Varga J, Trojanowska M, Kuwana M. Pathogenesis of systemic sclerosis: recent insights of molecular and cellular mechanisms and therapeutic opportunities. J Scleroderma Relat. 2017;2(3):137-52.

2. John Varga MT, Kuwana M. Pathogenesis of systemic sclerosis: recent insights of molecular and cellular mechanisms and therapeutic opportunities. J scleroderma relat disord. 2017;2(3):137-52.

3. Pober JS, Sessa WC. Evolving functions of endothelial cells in inflammation. Nat Rev Immunol. 2007;7(10):803-15.

4. Cho JG, Lee A, Chang W, Lee MS, Kim J. Endothelial to mesenchymal transition represents a key link in the interaction between inflammation and endothelial dysfunction. Front Immunol. 2018;9:294.

5. Piera-Velazquez S, Mendoza FA, Jimenez SA. Endothelial to Mesenchymal Transition (EndoMT) in the Pathogenesis of Human Fibrotic Diseases. J Clin Med. 2016:5(4):45.

6. Manetti M, Romano E, Rosa I, Guiducci S, Bellando-Randone S, De Paulis A, Ibba-Manneschi L, Matucci-Cerinic M. Endothelial-to-mesenchymal transition contributes to endothelial dysfunction and dermal fibrosis in systemic sclerosis. Ann Rheum Dis. 2017;76(5):924-34.

7. Rose-John S. Interleukin-6 Family Cytokines. Cold Spring Harb Perspect Biol. 2018;10(2):a028415.

8. Rincon M. Interleukin-6: from an inflammatory marker to a target for inflammatory diseases. Trends Immunol. 2012;33(11):571-7.

9. Kishimoto T, Kang S, Tanaka T. IL-6: A New Era for the Treatment of Autoimmune Inflammatory Diseases. In: Nakao K, Minato N, Uemoto S, eds. Innovative Medicine: Basic Research and Development. Tokyo: Springer; 2015:131-47.

Grace Marden: Performed the research: data acquisition and analysis; revised the manuscript and gave final approval. Qianqian Wan: Performed the research: data acquisition and analysis, and gave final approval. James Wilks: Performed the research: data acquisition and analysis. Katherine Nevin: Conception and design of the study; revised the manuscript and gave final approval. Maria Feeney: Conception and design of the study; revised the manuscript and gave final approval. Nicolas Wisniacki: Conception and design of the study; revised the manuscript and gave final approval. Marcin Trojanowski: Provided skin biopsies, contributed to analysis and data interpretation, gave final approval.Andreea Bujor: Provided skin biopsies, contributed to analysis and data interpretation, and gave final approval. Lukasz Stawski: Performed the research; conception, design, data acquisition, analysis, and interpretation; drafting the manuscript; and gave final approval. Maria Trojanowska: Conception and design of the study, data analysis and interpretation; drafting the manuscript, revised the manuscript, and gave final approval.

\section{Funding}

This work was supported in part by the National Institutes of Health National Institute of Arthritis and Musculoskeletal Skin Disease grants R01 AR44883 (MT) and in part by collaboration funded by GSK (COL300028804).

\section{Availability of data and materials}

Datasets related to this article can be found at DOl: https://doi.org/10.17632/ 5h6w6jjjms.1\#folder-762c7894-d8f8-4124-ac6a-f2d22a170c5e

\section{Ethics approval and consent to participate}

Informed consent was obtained from all subjects, and the study was conducted in compliance with Institutional Review Board guidelines.

\section{Consent for publication}

Not applicable.
10. Schwartz DM, Kanno Y, Villarino A, Ward M, Gadina M, O'Shea JJ. JAK inhibition as a therapeutic strategy for immune and inflammatory diseases. Nat Rev Drug Discov. 2017;16(12):843-62.

11. Stawski L, Trojanowska M. Oncostatin M and its role in fibrosis. Connect Tissue Res. 2019;60(1):40-49.

12. Mozaffarian A, Brewer AW, Trueblood ES, Luzina IG, Todd NW, Atamas SP, Arnett HA. Mechanisms of oncostatin M-induced pulmonary inflammation and fibrosis. J Immunol. 2008;181(10):7243-53.

13. Chrobak I, Lenna S, Stawski L, Trojanowska M. Interferon-gamma promotes vascular remodeling in human microvascular endothelial cells by upregulating endothelin (ET)-1 and transforming growth factor (TGF) beta2. J Cell Physiol. 2013;228(8):1774-83.

14. Richard L, Velasco P, Detmar M. Isolation and culture of microvascular endothelial cells. Methods Mol Med. 1999;18:261-9.

15. Karkampouna S, Kloen P, Obdeijn MC, Riester SM, van Wijnen AJ, Kruithofde Julio M. Human Dupuytren's Ex Vivo Culture for the Study of Myofibroblasts and Extracellular Matrix Interactions. J Vis Exp. 2015;(98): 52534.

16. Stifano $G$, Sornasse $T$, Rice LM, Na L, Chen-Harris H, Khanna D, Jahreis A Zhang $Y$, Siegel J, Lafyatis R. Skin gene expression is prognostic for the trajectory of skin disease in patients with diffuse cutaneous systemic sclerosis. Arthritis Rheumatol. 2018;70(6):912-9.

17. Ruprecht K, Kuhlmann T, Seif F, Hummel V, Kruse N, Bruck W, Rieckmann P. Effects of oncostatin M on human cerebral endothelial Neurol. 2001;60(11):1087-98.

18. Yao L, Pan J, Setiadi H, Patel KD, McEver RP. Interleukin 4 or oncostatin M induces a prolonged increase in P-selectin mRNA and protein in human endothelial cells. J Exp Med. 1996;184(1):81-92.

19. Wijelath ES, Carlsen B, Cole T, Chen J, Kothari S, Hammond WP. Oncostatin $M$ induces basic fibroblast growth factor expression in endothelial cells and cells and expression in inflammatory brain lesions. J Neuropathol Exp 
promotes endothelial cell proliferation, migration and spindle morphology. J Cell Sci. 1997;110(Pt 7):871-9.

20. Alexander RA, Prager GW, Mihaly-Bison J, Uhrin P, Sunzenauer S, Binder BR, Schutz GJ, Freissmuth M, Breuss JM. VEGF-induced endothelial cell migration requires urokinase receptor (UPAR)-dependent integrin redistribution. Cardiovasc Res. 2012:94(1):125-35.

21. Lemos DR, Duffield JS. Tissue-resident mesenchymal stromal cells: Implications for tissue-specific antifibrotic therapies. Sci Transl Med. 2018; 10(426):eaan5174.

22. Ho YY, Baron M, Recklies AD, Roughley PJ, Mort JS. Cells from the skin of patients with systemic sclerosis secrete chitinase 3-like protein 1. BBA Clin. 2014;1:2-11.

23. Kumagai E, Mano Y, Yoshio S, Shoji H, Sugiyama M, Korenaga M, Ishida T, Arai T, Itokawa N, Atsukawa M, et al. Serum YKL-40 as a marker of liver fibrosis in patients with non-alcoholic fatty liver disease. Sci Rep. 2016;6:35282.

24. Lee CG, Herzog EL, Ahangari F, Zhou Y, Gulati M, Lee CM, Peng X, FeghaliBostwick C, Jimenez SA, Varga J, et al. Chitinase 1 is a biomarker for and therapeutic target in scleroderma-associated interstitial lung disease that augments TGF-beta1 signaling. J Immunol. 2012;189(5):2635-44.

25. Nordenbaek C, Johansen JS, Halberg P, Wiik A, Garbarsch C, Ullman S, Price PA, Jacobsen S. High serum levels of YKL-40 in patients with systemic sclerosis are associated with pulmonary involvement. Scand J Rheumatol. 2005;34(4):293-7.

26. Lagendijk AK, Szabo A, Merks RM, Bakkers J. Hyaluronan: a critical regulator of endothelial-to-mesenchymal transition during cardiac valve formation. Trends Cardiovasc Med. 2013;23(5):135-42.

27. Li Y, Jiang D, Liang J, Meltzer EB, Gray A, Miura R, Wogensen L, Yamaguchi $Y$, Noble PW. Severe lung fibrosis requires an invasive fibroblast phenotype regulated by hyaluronan and CD44. J Exp Med. 2011;208(7):1459-71.

28. Sanchez-Duffhues G, Garcia de Vinuesa A, Ten Dijke P. Endothelial-tomesenchymal transition in cardiovascular diseases: developmental signaling pathways gone awry. Dev Dyn. 2018;247(3):492-508.

29. Daoussis D, Papachristou DJ, Dimitroulas T, Sidiropoulos T, Antonopoulos I, Andonopoulos AP, Liossis SN: Dickkopf-1 is downregulated early and universally in the skin of patients with systemic sclerosis despite normal circulating levels. Clin Exp Rheumatol 2018, 36 Suppl 113(4):45-49.

30. Dees C, Schlottmann I, Funke R, Distler A, Palumbo-Zerr K, Zerr P, Lin NY, Beyer C, Distler O, Schett G, et al. The Wnt antagonists DKK1 and SFRP1 are downregulated by promoter hypermethylation in systemic sclerosis. Ann Rheum Dis. 2014;73(6):1232-9.

31. Chakraborty D, Sumova B, Mallano T, Chen CW, Distler A, Bergmann C, Ludolph I, Horch RE, Gelse K, Ramming A, et al. Activation of STAT3 integrates common profibrotic pathways to promote fibroblast activation and tissue fibrosis. Nat Commun. 2017:8(1):1130.

32. Pedroza M, Le TT, Lewis K, Karmouty-Quintana H, To S, George AT, Blackburn MR, Tweardy DJ, Agarwal SK. STAT-3 contributes to pulmonary fibrosis through epithelial injury and fibroblast-myofibroblast differentiation. FASEB J. 2016;30(1):129-40.

33. Asano Y, Stawski L, Hant F, Highland K, Silver R, Szalai G, Watson DK, Trojanowska M. Endothelial Fli1 deficiency impairs vascular homeostasis: a role in scleroderma vasculopathy. Am J Pathol. 2010;176(4):1983-98.

34. Looney AP, Han R, Stawski L, Marden G, Iwamoto M, Trojanowska M. Synergistic role of endothelial ERG and FLI1 in mediating pulmonary vascular homeostasis. Am J Respir Cell Mol Biol. 2017;57(1):121-31.

35. Nagai $N$, Ohguchi $H$, Nakaki R, Matsumura $Y$, Kanki $Y$, Sakai J, Aburatani $H$, Minami T. Downregulation of ERG and FLI1 expression in endothelial cells triggers endothelial-to-mesenchymal transition. PLoS Genet. 2018;14(11):e1007826.

36. Didion SP. Cellular and Oxidative Mechanisms Associated with Interleukin-6 Signaling in the Vasculature. Int J Mol Sci. 2017;18(12):2563.

37. O'Reilly S, Ciechomska M, Cant R, Hugle T, van Laar JM. Interleukin-6, its role in fibrosing conditions. Cytokine Growth Factor Rev. 2012;23(3):99-107.

38. Hasegawa M, Sato S, Fujimoto M, Ihn H, Kikuchi K, Takehara K. Serum levels of interleukin 6 (IL-6), oncostatin M, soluble IL-6 receptor, and soluble gp130 in patients with systemic sclerosis. J Rheumatol. 1998:25(2):308-13.

39. Hasegawa M, Sato S, Ihn H, Takehara K. Enhanced production of interleukin6 (IL-6), oncostatin M and soluble IL-6 receptor by cultured peripheral blood mononuclear cells from patients with systemic sclerosis. Rheumatology (Oxford). 1999;38(7):612-7.

40. Kasembeli MM, Bharadwaj U, Robinson P, Tweardy DJ. Contribution of STAT3 to Inflammatory and Fibrotic Diseases and Prospects for its Targeting for Treatment. Int J Mol Sci. 2018;19(8):2299.
41. Dey G, Radhakrishnan A, Syed N, Thomas JK, Nadig A, Srikumar K, Mathur PP, Pandey A, Lin SK, Raju R, et al. Signaling network of Oncostatin M pathway. J Cell Commun Signal. 2013;7(2):103-8.

42. Wang Y, van Boxel-Dezaire AH, Cheon H, Yang J, Stark GR. STAT3 activation in response to IL- 6 is prolonged by the binding of IL-6 receptor to EGF receptor. Proc Natl Acad Sci U S A. 2013;110(42):16975-80.

43. Kim KJ, Kwon SH, Yun JH, Jeong HS, Kim HR, Lee EH, Ye SK, Cho CH. STAT3 activation in endothelial cells is important for tumor metastasis via increased cell adhesion molecule expression. Oncogene. 2017;36(39): 5445-59.

44. Wei Z, Jiang W, Wang H, Li H, Tang B, Liu B, Jiang H, Sun X. The IL-6/STAT3 pathway regulates adhesion molecules and cytoskeleton of endothelial cells in thromboangiitis obliterans. Cell Signal. 2018;44:118-26.

45. Blanchard F, Wang Y, Kinzie E, Duplomb L, Godard A, Baumann H. Oncostatin $\mathrm{M}$ regulates the synthesis and turnover of gp130, leukemia inhibitory factor receptor alpha, and oncostatin $\mathrm{M}$ receptor beta by distinct mechanisms. J Biol Chem. 2001;276(50):47038-45.

46. Salvador B, Arranz A, Francisco S, Cordoba L, Punzon C, Llamas MA, Fresno M. Modulation of endothelial function by toll like receptors. Pharmacol Res. 2016;108:46-56.

47. Murdaca G, Colombo BM, Cagnati P, Gulli R, Spano F, Puppo F. Endothelial dysfunction in rheumatic autoimmune diseases. Atherosclerosis. 2012;224(2): 309-17.

48. Akamata K, Asano Y, Yamashita T, Noda S, Taniguchi T, Takahashi T, Ichimura Y, Toyama T, Trojanowska M, Sato S. Endothelin receptor blockade ameliorates vascular fragility in endothelial cell-specific Fli-1-knockout mice by increasing Fli-1 DNA binding ability. Arthritis Rheumatol. 2015;67(5): 1335-44.

49. Stawski L, Marden G, Trojanowska M. The activation of human dermal microvascular cells by poly(l:C), lipopolysaccharide, Imiquimod, and ODN2395 is mediated by the Fli1/FOXO3A pathway. J Immunol. 2018; 200(1):248-59.

50. van Bon L, Affandi AJ, Broen J, Christmann RB, Marijnissen RJ, Stawski L, Farina GA, Stifano G, Mathes AL, Cossu M, et al. Proteome-wide analysis and CXCL4 as a biomarker in systemic sclerosis. N Engl J Med. 2014;370(5):43343.

51. Yuan L, Nikolova-Krstevski V, Zhan Y, Kondo M, Bhasin M, Varghese L, Yano K, Carman CV, Aird WC, Oettgen P. Antiinflammatory effects of the ETS factor ERG in endothelial cells are mediated through transcriptional repression of the interleukin-8 gene. Circ Res. 2009;104(9):1049-57.

52. Saito F, Tasaka S, Inoue K, Miyamoto K, Nakano Y, Ogawa Y, Yamada W, Shiraishi Y, Hasegawa N, Fujishima S, et al. Role of interleukin-6 in bleomycin-induced lung inflammatory changes in mice. Am J Respir Cell Mol Biol. 2008;38(5):566-71.

53. Kitaba S, Murota H, Terao M, Azukizawa H, Terabe F, Shima Y, Fujimoto M, Tanaka T, Naka T, Kishimoto T, et al. Blockade of interleukin-6 receptor alleviates disease in mouse model of scleroderma. Am J Pathol. 2012;180(1): $165-76$.

54. Wong S, Botelho FM, Rodrigues RM, Richards CD. Oncostatin M overexpression induces matrix deposition, STAT3 activation, and SMAD1 Dysregulation in lungs of fibrosis-resistant BALB/c mice. Lab Investig. 2014; 94(9):1003-16.

55. Poling J, Gajawada P, Richter M, Lorchner H, Polyakova V, Kostin S, Shin J, Boettger T, Walther T, Rees W, et al. Therapeutic targeting of the oncostatin M receptor-beta prevents inflammatory heart failure. Basic Res Cardiol. 2014; 109(1):396.

56. Matsuda M, Tsurusaki S, Miyata N, Saijou E, Okochi H, Miyajima A, Tanaka M. Oncostatin M causes liver fibrosis by regulating cooperation between hepatic stellate cells and macrophages in mice. Hepatology. 2018;67(1):296-312.

57. Botelho FM, Rodrigues R, Guerette J, Wong S, Fritz DK, Richards CD. Extracellular Matrix and Fibrocyte Accumulation in BALB/C Mouse Lung upon Transient Overexpression of Oncostatin M. Cells. 2019;8(2):126.

58. Iwayama T, Olson LE. Involvement of PDGF in fibrosis and scleroderma: recent insights from animal models and potential therapeutic opportunities. Curr Rheumatol Rep. 2013;15(2):304.

59. Khanna D, Denton CP, Jahreis A, van Laar JM, Frech TM, Anderson ME, Baron M, Chung L, Fierlbeck G, Lakshminarayanan S, et al. Safety and efficacy of subcutaneous tocilizumab in adults with systemic sclerosis (faSScinate): a phase 2, randomised, controlled trial. Lancet. 2016;387(10038): 2630-40. 
60. Denton CP, Ong VH, Xu S, Chen-Harris H, Modrusan Z, Lafyatis R, Khanna D, Jahreis A, Siegel J, Sornasse T. Therapeutic interleukin-6 blockade reverses transforming growth factor-beta pathway activation in dermal fibroblasts: insights from the faSScinate clinical trial in systemic sclerosis. Ann Rheum Dis. 2018;77(9):1362-71.

\section{Publisher's Note}

Springer Nature remains neutral with regard to jurisdictional claims in published maps and institutional affiliations.

Ready to submit your research? Choose BMC and benefit from:

- fast, convenient online submission

- thorough peer review by experienced researchers in your field

- rapid publication on acceptance

- support for research data, including large and complex data types

- gold Open Access which fosters wider collaboration and increased citations

- maximum visibility for your research: over $100 \mathrm{M}$ website views per year

At $\mathrm{BMC}$, research is always in progress.

Learn more biomedcentral.com/submissions 